\title{
Swedish Tax News
}

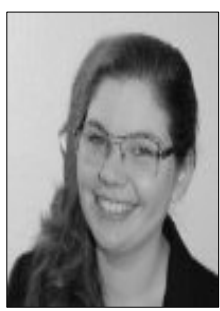

Jur.Dr, Senior lecturer Pernilla Rendahl The School of Business, Economics and Law, Gothenburg University

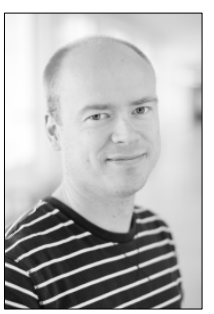

Jur.Dr, Senior lecturer David Kleist

The School of Business,

Economics and Law,

Gothenburg University

The objective of this section is to give an overview of legislative changes of interest to an international audience that have been decided in the previous half year period, i.e. for this issue of Nordic Tax Journal the period from 1 January 2014 until 30 June 2014. In addition, it includes a brief introduction to a selection of tax cases from the Swedish Supreme Administrative Court, Högsta Förvaltningsdomstolen (»HFD"), that have been delivered during the same period and can be assumed to be of interest to readers outside Sweden.

This time there has not been any legislative changes worth mentioning. However, a proposal for a reform of Swedish Corporate Taxation has been presented, which is described briefly and commented on below. Furthermore, we present a couple of court cases that we consider to be of particular interest.

\section{Proposal for Reform of Swedish Corporate Taxation}

\subsection{Introduction}

On 12 June 2014, the Committee on Corporate Income Taxation (below referred to as the "Committee"), which commenced work in 2011, presented its 900 pages report regarding a reform of the Swedish corporate tax system. The Report is entitled A Neutral Corporate Tax for Increased Efficiency and Stability (below referred to as the "Com- 
mittee Report"). ${ }^{1}$ The changes are proposed to enter into effect on 1 January 2016.

The Committee Report contains a main proposal and an alternative, less radical, proposal. Under the main proposal, interest costs exceeding interest income (below referred to as "net financial expense") will be non-deductible. Instead, all enterprises will be allowed a basic allowance of 25 per cent of the taxable income (i.e. the taxable income excluding the basic allowance and excluding deduction for any net financial expense), so that only 75 per cent of the taxable income will be subject to the Swedish corporate tax of 22 per cent. In effect this means that the corporate tax rate for enterprises that do not have any net financial expense is lowered from 22 per cent to 16.5 per cent, whereas enterprises that according to the current rules can deduct net financial expense in excess of the basic allowance face an increase of the tax burden.

\subsection{Main Features of the Proposal}

As described above, net financial expense will be non-deductible, meaning that interest costs in excess of interest income will be nondeductible. The definition of net financial expense will cover not only interest expense, but also other financial expenses such as foreign exchange losses, deductible losses on financial instruments and, with certain exceptions, lease fees that are deemed to correspond to interest.

As a consequence of the fact that net financial expense will be nondeductible, there will no longer be any need for the current rather technical and complicated rules on interest deduction limitations.

Companies within a group that qualify for shifting income according to the Swedish rules on group contribution will also be entitled to set off net financial expense of one company against net financial income of another company.

Enterprises in the financial services sector such as banks typically have positive net interest income and are therefore normally not affected by the non-deductibility of net financial expense. As there is no intention to reduce the tax burden in the financial services sector, a yield tax is proposed for such companies. The yield tax shall be computed as 0.24 per cent of the amount of debt in the balance sheet.

According to the assessment made by the Committee, the reform as a whole is not intended to have any effect on the national budget. In principle, the loss of tax revenue due to the introduction of the basic 
allowance should be compensated by the increase of tax revenue due to the non-deductibility of net interest expense.

Under Swedish tax law losses may be carried forward indefinitely. However, as part of the financing of the reform the Committee also proposes that only 50 per cent of losses carried forward under the current rules may be carried forward to the year in which the new rules enter into force. In other words, half the amount of losses carried forward will be lost. The justification for this is that the losses "to a significant extent have arisen in a period during which it has been possible to create losses by means of interest deduction". 2 Presumably, the Committee means that a significant share of the tax losses carried forward by Swedish enterprises are due to excessive interest deductions. However, the proposal seems rather arbitrary in this regard as the reduction will affect all losses carried forward.

\subsection{The Alternative Proposal}

As an alternative, the Committee proposes that deduction for net financial expense shall be limited to 20 per cent of EBIT. This is combined with a reduction of the nominal corporate tax rate from 22 per cent to 18.5 per cent.

Non-deductible net financial expense (i.e. net financial expense in excess of 20 per cent of EBIT) may be carried forward up to six years so that enterprises whose profits follow the business cycle shall not be worse off than enterprises with more stable profits.

The alternative proposal requires more rules for preventing tax avoidance than the main proposal, leading to increased complexity. For instance, under the alternative proposal the current interest deduction limitation rules are proposed to remain unaltered.

\subsection{Comments}

The main proposal as well as the alternative proposal is in line with the general international trend of lowering the corporate tax rate while at the same time broadening the tax base by means of inter alia interest deduction limitations. Furthermore, limiting deduction for interest costs brings the tax treatment of debt closer to that of equity capital, as the injection of equity capital under most countries' legislation does not entitle an enterprise to any deduction. Neutral tax treatment of debt and equity capital is generally perceived as beneficial to the national economy. ${ }^{3}$ It also has the benefit of reducing the

2 The Committee Report, p. 301.

3 See Christian Thomann, Swedish National Report: Recent Developments in Corporate Taxation in Sweden, in this issue, with further references. 
opportunities for tax planning by means of excessive interest deductions. ${ }^{4}$

However, the main proposal of the Committee is probably more radical than the interest deduction limitations of any other country. Under most, if not all, countries' interest deduction limitations, interest costs are deductible as a main rule but deduction may be denied subject to certain conditions. For instance, deduction may be denied insofar as the interest costs exceed a certain per centage of EBIT ${ }^{5}$ or EBITDA $^{6}$, or if the company's financing structure is deemed excessively leveraged. Accordingly, under the Swedish current legislation, interest costs are generally deductible, but deduction may be denied where the lender is an associated enterprise, unless certain requirements are fulfilled (typically that the lender is subject to tax at a rate of at least 10 per cent). ${ }^{7}$ No such safe harbors exist under the Committee's main proposal - net interest expense will be non-deductible without exceptions.

The changes affect different types of businesses very differently depending mainly on the leverage among enterprises in each business sector. For instance, for the real estate sector, where investment is typically financed to a significant extent with bank loans, the nondeductibility of net financial expense will clearly lead to an increase of the tax burden, whereas enterprises that are typically financed with equity capital (e.g. medical research) or in little need of financing (such as consultancy firms, accounting firms and many other service providers) will benefit from the changes. ${ }^{8}$

Granting an allowance of 25 per cent of the taxable income and subjecting the net amount to the Swedish corporate tax of 22 per cent results in the same tax liability as if the taxable income before the basic allowance would have been subject to a corporate tax of 16.5 per cent, so why does the Committee formulate the proposal in the way it does? The Committee only briefly touches upon this issue in the Report. The Report contains the following statement.

4 This is an issue that is currently dealt with by the OECD in its work on Base Erosion and Profit Shifting, see Action Plan on Base Erosion and Profit Shifting, OECD 2013, pp. 16-17. A recommendation by the OECD regarding the design of domestic rules to limit base erosion via interest deductions and other financial payments is scheduled to be delivered in September 2015.

5 EBIT means earnings before interest and taxes.

6 EIBTDA means earnings before interest, taxes, depreciation and amortization.

7 For a brief description of the current Swedish interest deduction limitations, see David Kleist, in this issue.

8 For an overview of the leverage in different business sectors in Sweden, see Christian Thomann, ibid. 
As the proposal involves such a significant limitation of the right to deduct interest costs and other financial costs, the Committee believes that there is an advantage in replacing the interest deduction with another deduction, namely the basis allowance for financial costs, instead of lowering the corporate tax rate. This underlines the intentions behind the reform. ${ }^{9}$

To me this seems like a rather cryptic explanation. What does the Committee really mean? One can only speculate. Is it a matter of political tactics, i.e. is the intention to increase the possibilities for the proposal to become law by presenting it as a replacement of the deduction for net financial expense by another deduction rather than as a proposal that includes a reduction of the corporate tax rate? In contrast, the alternative proposal which according to the Committee has fewer benefits ${ }^{10}$ is presented as including a lowering of the corporate tax rate, perhaps to make it less palatable. Or is the purpose to avoid criticism on the international level for participating in a race to the bottom in corporate income taxation or perhaps to avoid problems with CFC taxation of foreign shareholders as a consequence of a low nominal tax rate?

It will be very interesting to see how the discussion concerning the proposal goes and whether, in the end, the proposal will lead to legislation. Denying deduction for net financial expense while at the same time granting a basic allowance of 25 per cent for all enterprises clearly would change the playing field for doing business in Sweden. Business sectors that are affected negatively by the proposal will of course have an incentive to mobilize resistance and to put pressure on politicians by pointing at negative consequences of the proposal. There is also the option of going for the alternative proposal which can be seen as a compromise between the current rules and the main proposal, but which lacks the appealing simplicity of the main proposal.

\section{Case law}

\subsection{Income Tax}

HFD 2014 ref. 25

According to Ch. $44 \mathrm{sec} .21$ of the Swedish Income Tax Act, a taxpayer who sells property that he or she has inherited shall apply the deceased person's historical acquisition cost for the property when calculating the capital gain or loss on the sale. In other words, any value in-

9 Committee Report, p. 195, the author's translation.

10 See e.g. pp. 332-333 of the Committee Report. 
crease that has occurred when the property was held by the deceased person as well as any value increase that has occurred subsequently will be taxed when the taxpayer who has inherited the property sells it.

The case is an advance ruling concerning the question whether this provision shall also be applied if the deceased person was resident outside Sweden and the transfer of property to the heir according to the legislation of the state where the deceased person was resident (in this case Denmark) results in taxation as if the property was sold at market value. If the deceased person would have been resident in Sweden, no such taxation would have taken place according to Swedish law in connection with the transfer of property to the heir.

According to the Board for Advance Tax Rulings (Sw. Skatterättsnämnden), the provision is only applicable in situations where property has been transferred to the seller without triggering taxation. In this context the Board referred to inter alia Swedish transfer pricing rules that result in a step-up of the acquisition value in cases where the seller has been taxed on the basis of the market value of the property. Correspondingly, the Board held that the acquisition value of the property for the purpose of computing a capital gain or loss on the sale shall be the fair market value of the property, which the property was considered sold for according to Danish rules.

However, HFD reversed the decision of the Board for Advance Tax Rulings. As there was no exception applicable in this case, HFD held that the provision concerning acquisition value for inherited property applies, meaning that a capital gain or loss on a sale of the property shall be computed on the basis of the historical cost regardless of any taxation that may have taken place in the residence state of the deceased person in connection with the transfer of property to the heir.

\subsection{VAT}

During the past six months several VAT cases have been remitted from the Supreme Administrative Court to the Administrative Courts of appeal. The background to these cases is a decision from April 9th 2014 concerning VAT on printing services. This section on case law is therefore concentrated to the case from April as well as a case from January 2014 on sale of shares in a subsidiary, the last one shedding some light on the aftermath of the SKF-cases.

\section{HFD 2014 ref. 1}

This case concerns a company claiming deduction of input VAT in December 2006 of 193180 SEK for consulting services bought from a Finnish company that assisted the Swedish company in selling a Finnish subsidiary. If the consulting service had a direct and immediate 
link to the sale of shares in the Finnish company deduction for input VAT would not be allowed. On the other hand, if the consulting service had a direct and immediate link with the economic activities carried out by the selling company, deduction would be allowed since the company carried out taxable activities. The tax authority decided that deduction for input VAT was not allowed whereas both the Administrative Court and the Administrative Court of Appeal found that the deduction was allowed. The Administrative Court of Appeal based its reasoning on the SKF-case. ${ }^{11}$

The Supreme Administrative Court starts by distinguishing between if the sale of shares in the Finnish subsidiary is a transfer assets within the scope of Ch. 3 sec. 25 in the Swedish VAT Act, implementing Article 19 in the VAT directive, or if it is exempt from VAT in accordance with Ch. 3 sec. 9 in the Swedish VAT Act, implementing Article 135 in the VAT directive. Furthermore, it argues that the purchased services are sale of shares and exempt from VAT, not a transfer of assets. The company agrees with the view that the purchased services are exempt from VAT. Secondly the Supreme Administrative Court also argues that if a deduction of input VAT of the services need to be decided upon in conjunction with that the services are exempt from VAT. The Tax Authority or the lower courts did not make such a decision, whereas the case was referred back to the Tax Authority.

The case is an example of the different steps that need to be taken in deciding the right to deduction where exempt supplies are either at hand or connected to the purchase the deduction is sought for. There are different steps that need to be considered.

The four steps to consider are:

1) Is the transaction a sale of shares or a transfer of assets?

2) If it is a sale of shares it is exempt from VAT and no deduction of input VAT arises.

3) If it is a transfer of assets it is outside the scope of VAT and no VAT is charged and consequently no deduction of input VAT is made.

4) If there are supporting services and these are connected to a sale of shares the first question is if that supporting service is exempt from VAT or not. If it is exempt no VAT is charged and no deduction can be made. If it is subject to VAT the possibility for deduction depends upon if the input VAT is directly and immediately linked to the exempt transaction or directly and immediately

11 RÅ 2010 ref 56. 
linked to a taxable activity carried out by the company purchasing the supporting services. In the later case a deduction of input VAT can be made where the service is considered as a general expense for the taxable activity.

HFD 2014 ref. 14

The background to this case derives from the Graphic Procédé case from the Court of Justice of the European Union. ${ }^{12}$ Before this case Sweden applied 25 per cent VAT on sales from printing houses to their customers, even if the concurrent supply from that costumer was at a 6 per cent VAT rate. Furthermore, the Swedish VAT Act at that time did not contain a provision on the possibility to use a credit note when VAT had been incorrectly charged until 1 January 2008.

The aftermath of the Graphic Procéde case has led to several court cases on the possibility to additional taxation of the customers of the printing houses since they previously were able to deduct input VAT of 25 per cent and the printing houses have been able to recover the difference between 25 and 6 per cent VAT from the Tax Authority. The first cases decided upon this question from HFD held that it was possible to charge the customers of the printing houses on the additional tax since reciprocity between output and input VAT otherwise could not be upheld. The court held that this was important to ensure neutrality. From a pure VAT perspective this is a correct principle, but one question that the court did not consider is if reciprocity should be upheld if it leads to an actual taxation of a taxable person where the tax burden cannot be passed on to the final consumer.

Besides the substantive VAT issues there are also important procedural consequences of this case. Issuing VAT on the costumers of the printing houses is a consequential change following the decision on lowering the VAT on the printing houses. The procedural provisions were previously found in Skattebetalningslagen (1997:483) but are now found in Skatteförfarandelagen (2011:1224). ${ }^{13}$ A consequential change of a tax decision cannot be made if it is undue (oskäligt). According to the Supreme Administrative court undue reasons are an exception to the provisions on after taxation and consequential changes. Support for this is held from a perspective of equality between similar cases. Furthermore, the court also holds that between taxable persons it is important to uphold not only equal treatment, but also competition neutrality by striving for a correct tax result as far as possible. I agree to the principle of equal treatment or rather neutrality between similar situations from a substantive VAT perspective. However, to my

12 C-88/09 Graphic Procédé [2010] REG I-1049.

13 Ch. 66, sec. 27,28 and 30. 
knowledge the ECJ has not judged in favour of neutrality on the expense of certainty. Hence, in this case there is a question of if procedural rules are second to a substantive VAT result or a correct taxation as referred to by the court. The court also holds that the core of the VAT is that the tax burden should be forwarded throughout the production- and distribution chain, however, as an argument to impose after taxation. If the after taxation, however, leads to the opposite result, it is in breach of the core purpose of the VAT as a tax on consumption.

In the aftermath of this case there are a number of cases before the Administrative Courts of Appeal and also the Courts of Appeal since this affects several general issues in procedural law and private law as well. One of the issues to be discussed is if the consequential decision in after taxation is undue or not.

From an EU perspective the Member States have an obligation to ensure the effects of EU law at national level and to ensure a proper application. The substantive VAT is harmonised within the EU to a larger extent than procedural rules. This question is not discussed by HFD. 